\title{
MORPHOLOGY, HISTOCHEMISTRY AND BIOCHEMISTRY OF FOLLICULAR GROWTH AND ATRESIA
}

\author{
S. S. GURAYA \\ Department of Zoology, \\ College of Basic Sciences and Humanities, \\ Punjab agricultural University, \\ Ludhiana, Punjab (India)
}

\section{SUMMARY}

Structure, function and interrelationships of various components of primordial and growing follicles have been determined by correlating the results of recent histochemical, biochemical and electron microscope studies on follicular growth. Various morphological, histochemical and biochemical alterations, which occur during follicular atresia, are related first to the disruption of normal in terrelationships among various components of follicle and then to their digestion and resorption in later stages of atresia. The most important significance of follicular atresia is the formation of ovarian interstitial gland cells from the theca interna and surrounding stroma of atretic follicles, which may secrete either androgens, or ostrogens, or progestogens depending upon the mammalian species. Their steroidal secretions must be of great significance in the reproductive processes of female and continued researches in this area are needed.

\section{INTRODUC'TION}

Follicular growth and atresia have been the subjects for several recent ultrastructural, histochemical and biochemical studies. The purpose of this paper is to integrate these results for a deeper insight into the structure, physiology and interrelationships of various components of follicle.

\section{I. - PRIMORDIAL FOLLICLES}

Primordial oocytes remain in an arrested meiotic prophase for a long time in the ovarian cortex (MAULÉON, I969). Various ooplasmic structures such as yolk nucleus, granular basophilic substance, mitochondria, and lipid bodies, form a juxta - or paranuclear complex which is usually designated as the Balbiani's vitelline 
body or yolk nucleus complex (GURAyA, I964, I965, I967 $a, b, \operatorname{Ig} 68 a, b, \operatorname{I970} a, b, c)$. Electron microscopic studies have revealed a rather simple large paranuclear aggregate of vesicles or saccules interpreted as a large Golgi complex or cytocentrum (HADEK, I965 ; Stegher, I967; HerTig and AdAMS, I967; Hertig, I968 ; NORREVANG, I968), which is identical to the yolk nucleus of histochemical studies. The relation of yolk nucleus consisting of RNA, protein and lipoprotein, to the Golgi complex is still unknown in the mammalian oocytes (HADEK, I965). Granular basophilic substance consisting mainly of RNA, protein and some lipoprotein, along with mitochondria, is uniformly distributed throughout the cytoplasm and corresponds to the ultrastructural RNP particles or ribosomes, and various profiles of endoplasmic reticulum (AdAMs and Hertig, I964; HADEK, I965; Stegner, I967; NorReVANG, I968). Sparsely distributed mitochondria having usual phospholipid-protein composition, show a great diversity in their ultrastructure (fig. I). Phospholipid bodies of variable size and morphology usually lie in association with other cytoplasmic components and in the peripheral ooplasm where they may be associated with pinocytotic vacuoles. In electron microscopic studies, they appear to have been either missed, or described by different names (see GuRAya, I970 b).

Primordial oocytes of human and chimpanzee also contain masses of stacked or concentric annulate lamellae, and heterogeneous spherical bodies (or ultrastructural large compound aggregates) (Hertig and AdAMs, I967; Hertig, I968; Guraya, I970 $a$; BARTON and HERTIG, I972). They consist of RNA and lipoprotein. Spherical bodies consisting of RNA and lipoprotein in young women undergo fatty metamorphosis by developing phospholipid-triglyceride granules in women in their middle reproductive years, suggesting that human primordial oocytes become aged in terms of somatic cell life (GURAYA, I967 $a$, I970 $a$ ).

The chromosomes in the nucleus of primordial oocytes develop the configuration of lampbrush and act as a site for the synthesis of RNA and proteins (fig. I) (see references in BAKER and FRANCHI, I967 $a, b$, I972). Ribonucleoproteins demonstrated histochemically in the ooplasm and its organelles must be derived from the lampbrush chromosomes. Their transference into the ooplasm may be facilitated by the development of pores or annules in the nuclear envelope (fig. I). Even some cytoplasmic inclusions originate from the nuclear envelope during early growth and differentiation of primordial oocyte (BAKER and FRANCHI, I969; BAKER, I970); the process of blebbing involved in their formation may also help in the transfer of informational macromolecules from nucleus into the ooplasm. BAKER (I970) has suggested that small primordial oocytes utilize some of their RNA as messenger for protein synthesis by ribosomes in the cytoplasm.

Mitochondria, phospholipid bodies, Golgi complex, granular endoplasmic reticulum and free ribosomes are seen in follicle cells of primordial oocytes (fig. I) Phospholipid bodies associated with vacuoles may be taken up by a phagocytic mechanism at the oocyte surface (GURAYA, I970 $a, b, c)$. The presence of similar phospholipid bodies in the ooplasm, follicle cells and surrounding stromal cells clearly suggests some close functional interrelationships between them (GURAYA, I970 a). Primordial oocytes are metabolically active as also supported by the continuous synthesis of nuclear ribonucleoproteins in them irrespective of whether the nuclear configuration of the diplotene or dictyate type (ROVERSI and SILVESTRINI, I963; OAKBERG, I966; BAKER et al., I969). 


\section{II. - FOLLICULAR GROWTH}

\section{A. - Sites of steroidogenesis}

Theca interna or granulosa or both are believed to constitute sites for steroidogenesis.

a) Theca interna.

Vascularized theca interna cells develop the ultrastructural, histochemical and biochemical features of steroid-secreting cells (see CHRISTENSEN and GILIM, I969; GuRAYA, I97I $a$, I972 $a, b$ for discussion). These features are : $a$ ) abundant diffuse lipids (lipoproteins) in the cytoplasm, which apparently derive from abundant ultrastructural agranular endoplasmic reticulum; $b$ ) well-developed cell organelles, especially mitochondria with complex system of internal cristae ; c) development of diffuse lipoproteins (or agranular endoplasmic reticulum), closely accompanied by the appearance of enzyme activities indicative of steroidogenesis ; d) under certain physiological situations stored lipid droplets in the cytoplasm, which greatly vary in their amount and histochemical composition in different mammalian species, and consist of either phospholipids, or phospholipids, triglycerides or phospholipids, triglycerides, and cholesterol and/or its esters; and $e$ ) capacity to form steroid hormones in biochemical experiments in vitro. In general, the results of cytological, histochemical and biochemical studies agree well with each other and are compatible with the endocrine function of theca interna cells. Species variations in regard to the development of these features, seem to be quantitative rather than qualitative in nature. Since oestradial-I7 $\beta$ and oestrone are considered to be the major radioactive products formed from acetate-I- ${ }^{14} \mathrm{C}$ and other labelled precursors by antral follicles (see GuRAYA, I97I $a$ ), such steroids must also be secreted in vivo by the theca interna.

\section{b) Granulosa cells.}

Granulosa cells of growing follicles develop the ultrastructural and histochemical features of actively growing and protein-synthesizing cells (fig. 2) (see GurAYA, I97I $a$; JAсову, I962). These features are : a) abundant RNA in the cytoplasm, which derives from free ribosomes and granular endoplasmic reticulum; $b$ ) welldeveloped Golgi complex, and mitochondria with simple system of internal cristae ; c) sparsely scattered phospholipid bodies of variable size and shape, which are very similar to those of growing oocyte and are not preserved well in electron microscope preparations ; $d$ ) well-developed nucleoli and heterochromatin masses in the nucleus (fig. 2) ; and $e$ ) lack of abundant diffuse lipoproteins (or membranes of smooth reticulum) (fig. 2) and their associated enzyme activities indicative of steroidogenesis. Various enzymes such as acid phosphatase, alkaline phosphatase, nucleoside monophosphatase, glycolytic enzymes, enzymes of citric acid cycle etc., showing several species variations, have also been reported in the granulosa cells (see JACOBY, I962 ; ADAMs et al., I966; BRANDAU, I970 for discuss on). These various features show 
that the granulosa cells in vivo are indeed metabolically active, this activity is clearly indicative of protein rather than lipid (or steroid) synthesis. The steroid metabolism in in vitro biochemical experiments by the granulosa cells has been studied in some investigations and valuable information has been obtained on steroid biosynthesis in these cells (see GURAYA, I97 I $a$, I972 $a$ for discussion). These studies, however, appear to express biochemical potentials of granulosa cells and not necessarily their secretory activity in vivo.

\section{B. - Oocyte growth}

a) Organelles.

With the initiation of growth in primordial oocyte, the paranuclear complex of organelles forming Balbiani's vitelline body moves away from the nuclear envelope to become distributed in the outer ooplasm (fig. 2) (GuRAYA, I964, I965, I967 $a, b$, I968 $a, b$, I970 $b$, I972 c) ; simultaneously the yolk nucleus fragments. Further oocyte growth shows proliferation and accumulation of yolk nucleus (or Golgi) derivatives, mitochondria, granular basophilic substance (or ultrastructural free ribosomes and profiles of endoplasmic reticulum) and heterogeneous phospholipid bodies of variable size in the cortical ooplasm (fig. 2) (see also HADEK, I965; STEGNER, I967 ; NORREVANG, I968). Systems of cytoplasmic membranes and mitochondria show a great diversity in their development and structure in the growing oocyte of different mammals (HadeK, I965; Stegner, I967; Horrevang, ig68; Guraya, I970 b). The oocytes of ruminants show very unusual mitochondria having a ' rod-like' appendage (Senger and SAACKE, I970 ; FlEMING and SAACKE, I972). The close morphological relationship of mitochondria with the RNA-containing basophilic substance (or ultrastructural endoplasmic reticulum and ribosomes) or " intermitochondrial" substance during the oocyte growth suggests a functional relationship between them which may be involved in protein synthesis or mitochondrial multiplication. Besides the usual organelles, some workers have also described cytoplasmic filaments or fibrous material in the oocytes of some mammals (see ODOR and BLANDAU, I972).

Phospholipid bodies associated with pinocytotic vacuoles in the peripheral ooplasm are apparently transported from the follicle cells of growing oocyte, which also show similar lipid bodies (GURAYA, I970 $b$, I972 c). Heterogeneous phospholipid bodies, which form the most prominent feature of growing oocyte, have either been missed in electron microscope studies, or they correspond to the "vesicular conglomerates' or multivesicular bodies.

\section{b) Cortical granules.}

Cortical granules originate in the peripherally located Golgi masses or yolk nucleus derivatives of growing oocyte (SzoI,LOSI, I967; BACA and ZAMBONI, I967). They consist of carbohydrate-protein complex (GURAYA, I969a; FuÁCHON, I970).

\section{c) Deutoplasmic inclusions.}

Deutoplasmic inclusions occur in the form of yolk vesicles and lipid yolk granules which show several variations in their development in different mammals (GURAYA, I959, I960, I964, I965, I967 $a, b, \operatorname{Ig68} a, b, \operatorname{I969} b$, I970 $b$, I972 $c$ ). Wherever they 
are formed, the exact mode of their formation is still not known. Yolk vesicles in the oocytes of rat, hamster and primates including human, do not show any appreciable development of yolk material in their inside. They have not been much studied by electron microscopists (see HADEK, I965; NoRREVANG, I968). However, the corresponding yolk vesicles in the oocytes of some mammals develop variable amounts of yolk material consisting of carbohydrate-protein complex (see GURAYA, I970 $b$; NORBERG, I972 ; FLEMING and SAACKE, I972). Lipid yolk granules consisting mainly of phospholipids, also show several variations in their development in the oocytes of different mammals (GURAYA, I970 b). Fleming and SAACKE (I972) have observed a very close association of endoplasmic reticulum and mitochondria to the surface of lipid droplets in the cow oocyte. The exact physiological significance of these variations in the development of deutoplasmic inclusions in mammals is still not known. Wherever present, they could be important in providing nutrients for the final maturation and fertilization of the oocyte as well as development of the very early embryo. Ooplasmic organelles, ribonucleoproteins, and deutoplasmic inclusions formed during oocyte growth are rearranged to form conspicuous gradients in the ooplasm of the fully grown egg, which may be playing some important role in cell differentiation by influencing the nuclear and gene activity (see GURAYA, I $972 \mathrm{c}$ ). It is becoming increasingly clear that a large proportion of RNP produced by the lampbrush chromosomes of growing oocyte is stored in the cytoplasm and its organelles (DAvidson, I968; BURKHOLDER et al., I97I ; GURAYA, I972 c).

\section{d) Zona pellucida and roles of granulosa cells.}

Follicle cells or oocyte or both are believed to be involved in the formation of zona material (see STEgner, I967 ; NorRevaNG, I968; BAKER, I970). Our recent studies have not revealed any special ultrastructural formations in the ooplasm adjacent to the developing islands which can be correlated to the origin of zona material (fig. 2). However, a careful examination of follicle cell cytoplasm, especially of processes, reveals the presence of some flocculent and fibrillar material which is apparently similar to that of zona (fig. 2), indicating the role of follicle cells in the formation of zona material. It appears to me that the oocyte surface simply acts as the site for the polymerization and deposition of zona material which consists of carbohydrateprotein complex.

Corona radiata cells and other granulosa cells apparently contribute phospholipid bodies, glycogen, and possibly some ribonucleoproteins to the growing oocyte (see Guraya, I969 $b, c$, I970 $b$, I972 $c$; WimsatT and Parks, I966; Baker, I970). The exact mechanisms of their transference from corona cells into the oocyte are still not known. Diffusion, pinocytosis, phagocytosis and phosphatases are believed to play significant roles in this regard since there is no direct cytoplasmic continuity between follicle cell processes and oocyte (HADEK, I965 ; ADAMs et al., I966 ; NoRREVANG, I968). Cells forming the cumulus and corona radiata under the normal preovulatory stimuli undergo some change (NORMAN and GREENWALD, I972), the nature of which is still not known. Foote and THIBaULT (r969), using in vitro techniques, have shown that nuclear maturation of oocyte depends upon physiological or mechanical isolation of oocyte from granulosa cells. 


\section{C. - Follicular fuid and ovulation}

Autoradiographic studies (see BJöRkmAN, r962) have shown active secretion of mucopolysaccharides by the granulosa cells, and high protein turn over. MERKER (I96I) and HADEK (I963) have visualized the emptying of large vesicles into the intercellular space, the vesicles seem to be derived from ergastoplasmic vesicles. These observations have suggested that the granulosa cells contribute some substances to the follicular fluid. But other workers believe that proteins of follicular fluid are directly derived from the blood vascularity of theca interna (see MANCINI et al., I963). Follicular fluid consists mainly of mucopolysaccharides (ZACHARIAE, I959; ЈАСову, I962). Steroid hormones derived from follicle wall also accumulate in the follicular fluid (YounglaI and SHorT, I970). Physical and chemical characteristics of its mucopolysaccharides are greatly changed during preovulatory swelling of follicle. These alterations are believed to increase an intrafollicular pressure which brings about ovulation in an explosive manner (see $Z_{\text {ACHARIAE, }}$ 959 for discussion). From the recent ultrastructural, histochemical and biochemical data on the process of ovulation, it has become increasingly clear that the rupture of a follicle is the result of a series of definitive degraded changes in the wall of follicle which are apparently brought about by lysosomal hydrolases, presumably in response to the action of LH (ESPEY, I97I ; BYSKov, I969; GURAYA, I97I b).

\section{III. - FOLI,ICULAR ATRESIA}

Follicular atresia is a wide spread phenomenon in the mammalian ovary by which majority of oocytes at various stages of their development are lost other than ovulation. Factors causing the follicular atresia may be variable depending upon the stage of follicular growth also (INGRAM, I962). HowEvER, it is becoming increasingly clear that the large secondary and tertiary follicles become atretic either due to the lack of proper gonadotrophic stimulation (INGRAM, I962 ; GURAYA and GREENWALD, I965) or due to imperfect balance of various hormones.

With the start of atresia, various components of follicle begin to undergo conspicuous morphological, histochemical and biochemical changes (LOBEL et al., I96I ; DEANE et al., I962; JACOBY, I962 ; INGRAM, I962; RUBIN et al., I963; GuRAYA and GREENWALD, I964, rg65; BeLTERMANN, I965; BAILLIE et al., I966; AdAMS et $a l .$, Ig66 ; BURKL and THIEL-BARTOSCH, I967 ; VAZQUEN-Niz and SoTELo, r967; LOBEL and LEVY, I968; MARION et al., I968; GURAYA, I97I $a, \operatorname{I972} a, b, \operatorname{I973} a, b)$. The most important criterion for follicular atresia at all stages including primordial follicles is the shrinkage of oocyte and granulosa (fig. 3, 4, 5). Relationship among oocyte microvilli, zona pellucida, and follicle cell processes is disrupted, and basement membrane disappears (fig. 5). The enzyme activities related to transport of substances into the oocyte and radioactive phosphorus of granulosa also disappear. The shrinkage also causes the abnormal structure, composition and distribution of organelles in atretic oocytes and their follicle cells ; the mitochondrial alterations seem to be the most significant signs of early degeneration. These changes during atresia 
may also be accompanied by the premature nuclear changes of bizarre appearance. As a result of various alterations in organelles, the whole living machinery of follicle is gradually disrupted (fig 3-6), and simultaneously some new cellular components namely lysosomes, cytolysosomes (or vacuoles) and myelin figures containing hydrolytic enzymes are developed to digest the various components of atretic follicle (GuRAYA, I969 b) ; macrophages also play significant role in their digestion. With the start of atresia, lipid droplets consisting mainly of triglycerides and some phospholipids (fig. 3 to 6), and glycogen begin to accumulate in the granulosa and oocyte. Species variations in regard to their amount commonly occur (fig. 3 to 6 ) and their significance is not known. The development of cholesterol-containing lipid droplets, diffuse lipoproteins and some enzyme activities indicative of steroidogenesis in the granulosa of atretic secondary and tertiary follicles suggests that they apparently undergo an incipient, non-functional luteinization in response to some luteinizing factors which become available with the initiation of atresia; the degree of their luteinization seems to vary in follicles of different sizes under different physiological situations. Granulosa cells of primordial and primary follicles appear to be relatively more resistant towards atresia as in some mammals they continue to persist after the disappearance of oocyte and form epithelial cords which may develop the histochemical features of steroid-secreting cells (GURAYA, I968c). These differences in the behaviour of granulosa cells in follicles of variable sizes during atresia in vivo, as well as in vitro (ODOR and BLANDAU, I972) clearly suggest that they undergo some basic metabolic changes during follicular growth, apparently in response to gonadotrophins and other environmental factors (see also CHANNING, I969, I970).

The granulosa cells and their lipid accumulations in atretic secondary and tertiary follicles degenerate and disappear leaving behind their hypertrophied thecae (fig. 3, 4), which finally form conspicuous patches of interstitial gland cells in the ovarian stroma. In their center are seen, sometimes, the remnants of degenerating oocyte and zona pellucida. The interstitial gland cells of thecal origin, develop abundant diffuse lipoproteins and lipid dropets (fig. 3-6), intense alkaline phosphatase activity, and various enzyme activities indicative of steroidogenesis (see GURAYA I97I $a, \operatorname{I973} a, b)$.

\section{Significance of follicular atresia}

Follicular atresia in the mammalian ovary is closely related to the formation of its interstitial gland cells from theca interna and surrounding stroma of atretic follicles (fig. 3, 4, 5, 6, 7), which form the most characteristic and important glandular looking tissue whose presence has been demonstrated clearly in the ovary of every mammalian species investigated (GURAYA, I972 $d$ ) ; its presence has also been shown convincingly even in the ovaries of non-pregnant women, rhesus monkey, cow and buffalo (fig. 6) in which it was denied with routine histological techniques. Although the interstitial gland cells greatly vary in their development and distribution in different mammalian species (fig. 3, 4,6) as well as with the ovarian cycle of the same mammal, they possess the cytological, histochemical and biochemical features of well-established steroid-secreting cells such as luteal cells (see reviews by GuRAYA, I97I $a, \operatorname{I972} a, b$, I973 $a, b$ ). Under certain physiological situations (with low levels of gonadotrophins) they store lipid droplets (fig. 3-6), which consist 
of triglycerides, cholesterol and cholesterol esters and phospholipids. In general the results of ultrastructural, histochemical and biochemical studies agree well with each other and are compatible with the endocrine function of ovarian interstitial gland cells which are believed to form androgens, oestrogens and progestogens depending upon the mammalian species (GURAYA, I973 $a, b$ ).

Interstitial gland cells of thecal origin are of very transient nature in the ovaries of some non-pregnant mammalian species (women, thesus monkey, cow and buffalo) as after persisting for some time in the wall of degenerated follicles (fig. 6) they generally revert to the relatively embryonic, compressed stromal tissue (fig. 7,8 ), leading to no accumulation in such ovaries. In the ovaries of other mammals showing a considerable development of interstitial gland cells they begin to accumulate rather than reverting back immediately to the original stromal tissue (fig. 3).

Since interstitial gland cells derived from theca interna of atretic follicles are present from young to old age and show cycles of abundance and differentiation correlated with the reproductive age and cycles, they seem to be the most important ovarian gland cells when their function is fully understood. Their secretory products may be of great physiological significance in the initiation of puberty and cyclic ovarian activity in the female.

\section{RÉSUMÉ}

CROISSANCE FOLLICULAIRE ET ATRÉSIE. ÉTUDE MORPHOLOGIQUE, HISTOCHIMIQUE ET BIOCHIMIQUE

La confrontation des résultats obtenus en histochimie, biochimie et microscopie électronique sur la croissance folliculaire permet de déterminer la structure et la fonction des divers composants des follicules primordiaux et en croissance.

Les altérations morphologiques, histochimiques et biochimiques qui se produisent au cours de l'atrésie, sont d'abord liées à la rupture des interrelations normales entre les divers composants du follicule. Dans les stades d'atrésie plus avancée, on observe leur résorption.

Le résultat le plus important de l'atrésie folliculaire est la formation de la glande interstitielle à partir de la thèque interne et du stroma qui entourent le follicule atrétique. Elle doit sécréter, selon les espèces, des androgènes, des œstrogènes ou des progestines.

Ces stéroïdes doivent jouer un rôle très important dans la reproduction de la femelle et méritent donc des recherches ultérieures.

\section{REFERENCES}

Adams E. C., Hertig A. T., I964. Studies on guinea pig oocytes. I. Electron microscopic observations on the development of cytoplasmic organelles in oocytes of primordial and primary follicles. $J$. Cell Biol., 21, 397-427.

Adams E. C., Hertig A. T., Foster S., 1966. Studies on guinea pig oocytes. II Histochemical observations on some phosphatases and lipid in developing and atretic oocytes. Amer. J.Anat., 119, 303-340.

BAcA M., ZAMboni L., I967. The fine structure of human follicular oocytes. J. Ultrastruct. Res., 19, 354-38r.

BAKER T. G., I970. Electron microscopy of the primary and secondary oocyte. Advanc. Biosci., 6, 7-27.

BAkER T. G., Franchi $\quad$ L. L., I967a. The fine structure of oogonia and oocytes in human ovaries. $J$. Cell Sci., 2, $213-224$. 
BAKER T. G., FranchI L. L., I $967 b$. The structure of the chromosomes in human primordial oocytes. Chromosoma (Berl.), 22, 358-377.

Baker T. G., Franchi L. L., I969. The origin of cytoplasmic inclusions from the nuclear envelope of mammalian oocytes. $Z$. Zelforsch., 98, 45-55.

BAKer T. G., Franchi L. L., 1972. The fine structure of oogonia and oocytes in the rhesus monkey (Macaca mulatta). Z. Zellforsch, 126, 53-74.

Baker T. G., Beaumont H. M., Franchi L. L., r969. The uptake of tritiated uridine and phenylalanine by the ovaries of rats and monkeys. J. Cell. Sci., 4, 655-675.

Baillie A. H., Ferguson M. M., HART D. M., I966. Developments in steroid histochemistry. Academic Press, London and New York.

Barton B. R., Hertig A. T., I972. Ultrastructure of annulate lamellae in primary oocytes of chimpanzees (Pan troglodytes). Biol. Reprod., 6, 98-108.

Beltermans R., I965. Elektronenmikroskopische Befunde bei beginnender Follikelatresie im Ovar der Maus, Arch Gynäk., 200, 60г-609.

BJörkman N., 1962. A study of the ultrastructure of the granulosa cells of the rat ovary. Acta anat. (Basel), 51, 125-147.

BrandaU H., I970. Histochemical localization of enzyme activities in normal and gonadotrophic stimulated infanct mouse ovaries. In : Butt, W. R., Crooke, A. C., Ryle M. Gonadotrophins and ovarian development, 307-3II, E. and S. Livingstone, Edinburgh and London.

Burkholder G. D., Comings D. E., Okada T. A., I97I. A storage form of ribosomes in mouse oocytes Exp. Cell Res., 69, 36I-372.

BURKL W., Thiel-Bartosch E., I967. Elektronenmikroskopische untersuchungen über die granulosa atresierender tertiärfollikel bei de Ratte. Arch Gynak., 204, 238-250.

Byskov A. G. S., r969. Ultrastructural studies on the preovulatory follicle in the mouse ovary. $Z$. Zellforsch., 100, 285-299.

Channing C. P., I969. The use of tissue culture of granulosa cells as a method of studying the mechanism of luteinizing. In : McKerns K. W. The Gonads, 415-490, Appleton-Century, New York.

Channing C. P., 197o. Influence of in vivo and in vitro hormonal environment upon luteinization of granulosa cells in tissue culture. Rec. progr. Horm. Res., 26, 589-622.

Christensen A. K., Gillim S. W., rg6g. The correlation of fine structure and function in steroidsecreting cells, with emphasis on those of the gonads. In : K. W. Mckerns. The gonads, 415-488, Appleton-century, New York.

Davidson E. H., 1968. Gene Activity in Early Development. Academic Press, New York.

Deane H. W., Lobel B. L., Romney S. L., 1962. Enzymic histochemistry of normal human ovaries of the menstrual cycle, pregnancy and the early puerperium. Amer. J. Obst. Gynec., 83, 281-294.

Fléchon J. E., 197o. Nature glycoprotéique des granules cortica ux de l'œuf de lapine. Mise en évidence par l'utilisation comparée de techniques cytochimiques ultrastruc turales.$J$. Microsc. (Paris), 9, $221-24 \mathrm{I}$.

Fleming W. N., SAacke R. G., I972. Fine structure of the bovine oocyte from the mature Graafian follicle. J. Reprod. Fert., 29, 203-213.

Foote W. D., Thibault C., I969. Recherches expérimentales sur la maturation in vitro des ovocytes de truie et de veau. Ann. Biol. anim. Biochem. Biophys., 9, 329-349.

Guraya S. S., I959. Histochemical studies of lipids in oocytes. III. Lipids in the oocytes of the rabbit and the hare. Res. Bull. Panjab Univ., 10, 81-97.

Guraya S. S., 1960. Histochemical studies of lipids in oocytes. VIII. Lipids in the oocy tes of the goat. Res. Bull. Panjab. Univ., 11, 173-181.

GuRAYA S. S., 1964. Histochemical studies on the yolk nucleus in the oogenesis of mammals. Am. $J$. Anat., 114, 283-292.

GuRaya S. S., I965. Histochemical analysis of lipid yolk deposition in the oocytes of cat and dog. $J$. Exp. Zool., 160, 123-136.

GurayA S. S., I967a. Cytological and cytochemical studies on the oocyte growth in primates. Res. Bull. Panjab. Univ., 18, 209-219.

GuRAYA S. S., I967 b. Cytochemical studies on changing localization of cell components during opoyte growth in grey bat. Res. Bull. Panjab Univ., 18, $221-230$.

GuRAyA S. S., I968 a. Histochemical study of the developing ovarian oocyte of the American opossum. Acta Embryol. Morph. Exp., 10, 181-191.

Guraya S. S., r968 b. A cytochemical study of cell components in the developing oocyte of the cattle ovary. Acta Vet. Acad. Sci. Hung., 18, 23-30.

GURAYA S. S., I 968 c. Comparative histochemical observations on the origin and function of epithelial cords in the mammalian ovary. VI ${ }^{\mathrm{e}}$ Cong. Intern. Reprod. anim. Insem. artif., Paris, vol. I, I4I-I43.

Guraya S. S., I969a. Histochemical nature of the cortical granules in the human egg. Z. Zellforsch., 94, 32-35.

Guraya S. S., I $969 b$. Histochemical study of lipids in the developing ovarian oocyte of the golden hamster (Mesocricetus auratus). Acta Anat. (Basel), 74, 65-75. 
GurayA S. S., I969 c. Histochemical observations concerning the transport of lipids into the developing oocyte of primates. Acta Morph. Neerl. Scand., 7, 21 I-2I7.

Guraya S. S., r970 a. Correlation between the findings of light and electron microscopy in human primordial follicles. Acta Anat. (Basel), 7y, 6r7-635.

Guraya S. S., I970 b. The histochemistry of the cytoplasm of the developing mammalian egg. Acta Embryol. Exp., 3, 227-254.

Guraya S. S., I970 $c$. Histochemical study of primordial oocyte in the golden hamster. Acta Morph. Neerl. Scand, 7 , 301-307.

GurayA S. S., I97I a. Morphology, histochemistry and biochemistry of human ovarian compartments and steroid hormone synthesis. Physiol. Rev., 51, 785-807.

GuRAYA S. S., I97I $b$. Histochemical observations on the nucleic acid changes of surrounding stroma with preovulatory swelling and ovulation in the rabbit. J. Reprod. Fert., 24, 107-108.

GurayA S.S., I972 a. Function of the human ovary during pregnancy as revealed by the histochemical, biochemical and electronmicroscope techniques. Acta Endocr. (Kbh), 69, Io7-I 8 .

GURAyA S. S., I972 $b$. Comparative studies on the histochemical features of ovarian compartments in the rat and golden hamster, with special reference to steroid hormone synthesis. Acta Anat. (Basel), 82, 284-304.

GurayA S. S., r972 c. Histochemical observations on the formation and nature of regional differences in the ooplasmic composition of the human ovum. Acta Anxt. (Basel), 81, 507-520.

Guraya S. S., I973a. Interstitial gland tissue of mammalian ovary. Acta Endocr. (Kbh), 12, Suppl. I7I.

Guraya S. S., r973 $b$. Correlations of histochemical, biochemical and electron microscopical findings on the bovine ovarian compartments in relation to biosynthesis of steroid hormones. in press.

Guraya S. S., Greenwald G. S., 1964. A comparative histochemical study of interstitial tissue and follicular atresia in the mammalian ovary. Anat. Rec., 149, 4I I-434.

Guraya S. S., Greenwald G.S., 1965. A histochemical study of the hamster ovary. Amer. J. Anat., 116, 257-266.

HADEK R., I963. Electron microscope study on primary liquor folliculi secretion in the mouse ovary. J. Ultrastruct. Res., 9, 445-458.

HADEK R., 1965. The structure of the mammalian egg. Int. Rev. Cytol., 18, 29-7I.

Hertig A. T., I968. The primary human oocyte : Some observations on the fine structure of Balbiani's vitelline body and the origin of the annulate lamellae. Amer. J. Anat., 122, 107-I38.

Hertig A. T., ADams E. C., I967. Studies on the human oocyte and its follicle. I. Ultrastructural and histochemical observations on the primordial follicle stage. J. Cell Biol., 34, 647-675.

INGRAM D. L., I962. Atresia. In : S. Zuckerman. The ovary, 247-266, Academic Press. London.

JAсовY F., I962. Ovarian histochemistry. In : S. Zuckerman. The ovary, I89-245, Academic Press, London.

Lobel B. L., Levr E., Ig68. Enzymic correlates of development, secretory function and regression of follicle and corpora lutea in the bovine ovary. Acta Endocr. (Kbh), 59, Suppl.

Lobel B. L., Rosenbaum R. M., Deane H. W., rg6r. Enzymic correlates of physiological regression of follicles and corpora lutea in ovaries of normal rats. Endocrinology, 68, 232-247.

Mancini R. E., Vilar O., Heinrich J. J., Davidson O. W., Alvarez B., ig63. Transference of circulating labelled serum proteins to the follicle of the rat ovary. J. Histochem. Cytochem., 11, 80.

Marion G. B., Gier H. T., Choudary J. B., I968. Micromorphology of the bovine ovarian follicular system. J. Anim. Sci., 27, $45 \mathrm{I}-465$.

MaulÉon P., Ig69. Oogenesis and folliculogenesis. In : H. H. Cole and P. T. Cupps. Reproduction in Domestic Animals, I87-2 I5, Academic Press, New York.

Merker H. J., I96r. Elektronenmikroskopische Untersuchungen über die Bildung der Zona pellucida in den Follikeln des Kaninchenovars. Z. Zellforsch., 54, 677-688.

Norberg H. S., 1972. The morphological relationship between mitochondria and cytoplasmic membranes of the follicular oocyte in domestic pig. Z. Zellforsch., 124, 520-531.

Norman R. L., Greenwald G. S., I972. Follicular histology and physiological correlates in the preovulatory hamster. Anat. Rec., 173, 95-108.

Norrevang A., 1968. Electron microscopic morphology of oogenesis. Int. Rev. Cytol., 23, II3-I86.

OAkBerg E. F., I966. ${ }^{3} \mathrm{H}$-uridine labeling of mouse oocytes In : Proceedings of the Colloquium on Physiology and Reproduction in Mammals, Paris. Archs Anat. microsc. Morph. exp., 56, Suppl.

IOdOR D. L., BLANDAU R. J., 1972. Ultrastructural observations on atresia in whole organ cultures of fetal mouse ovaries. The Development and Maturation of the Reproductive Organs and Functions in the Female. Workshop Meeting, July 3-5, Corpenhagen.

Roversi G. D., Silverstrini R., r963. Study on the protein metabolism of the evolutional ovarian follicle. Autoradiographic research with ${ }^{3} \mathrm{H}$-phenylalanine. Exp. Cell Res., 31, 484-489.

Rubin L. B., Deane H. W., Hamilton J. A., 1963. Biochemical and histochemical identification of $\Delta^{5}-3 \beta$-hydroxysteroid dehydrogenase activity in the adrenal cortex and ovaries of diverse mammals. Endocrinology, 78, 748-763. 
Senger P. L., SaAcke R. G., 1970. Unique mitochondria in the bovine oocyte. J. Cell Biol., 46, $405-408$.

StegneR H. E., 1967. Die elektronenmikroskopische Struktur der Eizelle. Ergebnisse der Anatomie und Entwicklungsgesichte, 39, 7-113.

Szollosi D., I967. Development of cortical granules and the cortical reaction in rat and hamster eggs. Anat. Rec., 159, 43 I-446.

Vazquez-Nin G. H., Sotelo J. R., 1967. Electron microscope study of the atretic oocytes of te rat. Z. Zellforsch, 81, 9I-99.

Wimsatt W. A., Parks H. F., r966. Ultrastructure of the surviving follicle of hibernation and of the ovum follicle cell relationship in the vespertilionid bat. Myotis lucifugus. In : I. W. Rolands, Comparative biology of reproduction, 4I9-454, Academic Press, London.

Younglat E. A., Short R. V., 1970. Pathways of steroid biosynthesis in the intact Graafian follicle of mares in cstrus. J. Endocr., 47, 321-333.

Zachariae F., r959. Acid mucopolysaccharides in the female genital system and their role in the mechanism of ovulation. Acta endocr. (Kbh), 33, Suppl. 46, I-64. 


\section{PLATE I}

FIG. I

Electron micrograph of portion of primordial follicle from day 2 postnatal ovary of guinea pig, showing that greater part of plasma membrane of oocyte is in close apposition to that of follicle or granulosa cells and desmosomes are seen. The ooplasm shows mitochondria having variable internal structure, free ribosomes, endoplasmic reticulum elements of different sizes and forms, and electron dense bodies. Similar cytoplasmic structures are also seen in the cytoplasm of granulosa cells, which show a Golgi complex also. Long processes arise from the granulosa cells. (After Guraya, Stegner and Pape, unpublished).

\section{FIG. 2}

Electron micrograph of portion of small preantral follicle from day 2 postnatal ovary of guinea pig, showing the formation of Zona pellucida between the follicular epithelium and oocyte surface. Note the flocculent and fibrillar material in the follicle cell cytoplasm, especially in follicle cell processes, which is similar to that of Zona material. The follicle cell cytoplasm also shows mitochondria of variable size, profiles of granular endoplasmic reticulum, and free ribosomes. Note some electron dense bodies both in follicle cell cytoplasm and ooplasm. The peripheral ooplasm shows a Golgi complex, mitochondria and elements of endoplasmic reticulum. (After GURAYA, STEGNER and PAPE, unpublished.)

\section{PLANCHE I}

FIG. I

Follicule primordial d'un ovaire de Cobaye 2 jours $p$. $p$. La majeure partie de la membrane plasmique de l'ovocyte est étroitement apposée à celle du follicule ou aux cellules de la granulosa. On observe des desmosomes. Le cytoplasme des cellules de la granulosa présente un Golgi complexe. De longs prolongements partent des cellules de la granulosa.

FIG. 2

Petit follicule préantral d'un ovaire de Cobaye 2 jours $p . p$. montrant la formation de la zone pellucide entre l'épithélium folliculaire et la surface de l'ovocyte. Noter le matériel flocculent et fibrillaire dans le cytoplasme des cellules folliculaires, semblable à celui de la zone pellucide. 
PLATE I

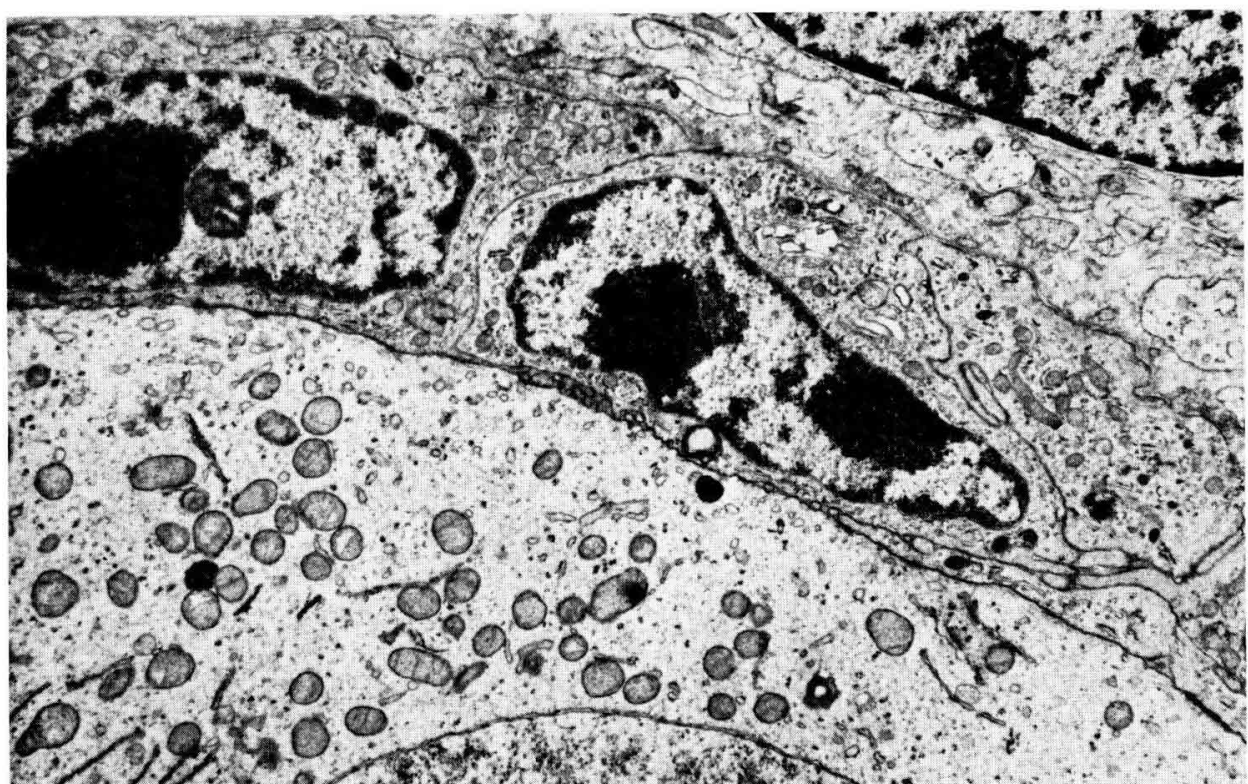

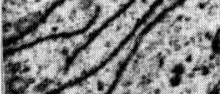




\section{PLATE II}

FIG. 3

Low power view of portion of guinea pig ovary from day 40 of pregnancy, showing normal follicle (NF), atretic follicles, (AF) in various stages of resorption of their granulosa, and formation of interstitial gland tissue (IGT). The interstitial gland tissue masses formed from the theca interna of atretic follicles gradually accumulate deeply sudanophilic lipids similar to those of corpus luteum (CL), while their granulosa cells after storing some sudanophilic lipids disintegrate and disappear.

Photomicrographs 3 to 8 have been prepared from frozen sections of ovarian material fixed in formaldehyde calcium, postchromed in dichromate calcium and coloured with Sudan black B.

\section{FIG. 4}

High power view of portion of guinea pig ovary from day 40 of pregnancy, showing disintegration and resorption of granulosa cells in atretic follicles (AF), leaving behind theca interna cells (TI) which simultaneously store sudanophilic lipids. The fully mature interstitial gland tissue masses (IGT) derived from theca interna of atretic follicles show heavy accumulation of deeply sudanophilic lipids (L) which are not seen in the compressed stroma (S) of ovary.

\section{PLANCHE II}

FIG. 3

Ovaire de cobaye à 40 jours de gestation montrant des follicules normaux (NF) et atrétiques ( $\mathrm{AF}$ ) à divers stades de résorption de la granulosa, avec formation de tissu interstitiel (IGT) qui accumule des lipides soudanophiles comme le corps jaune (CL).

FIG. 4

Ovaire de cobaye à 40 jours de gestation montrant la résorption des cellules de la granulosa dans les follicules atrétiques (AF). Les cellules de la thèque interne (TI) accumulent des granules soudanophiles. Le tissu interstitiel (IGT) montre une accumulation de lipides soudanophiles $(\mathrm{L})$ alors que le stroma ovarien (S) en est dépourvu. 
PLATE II
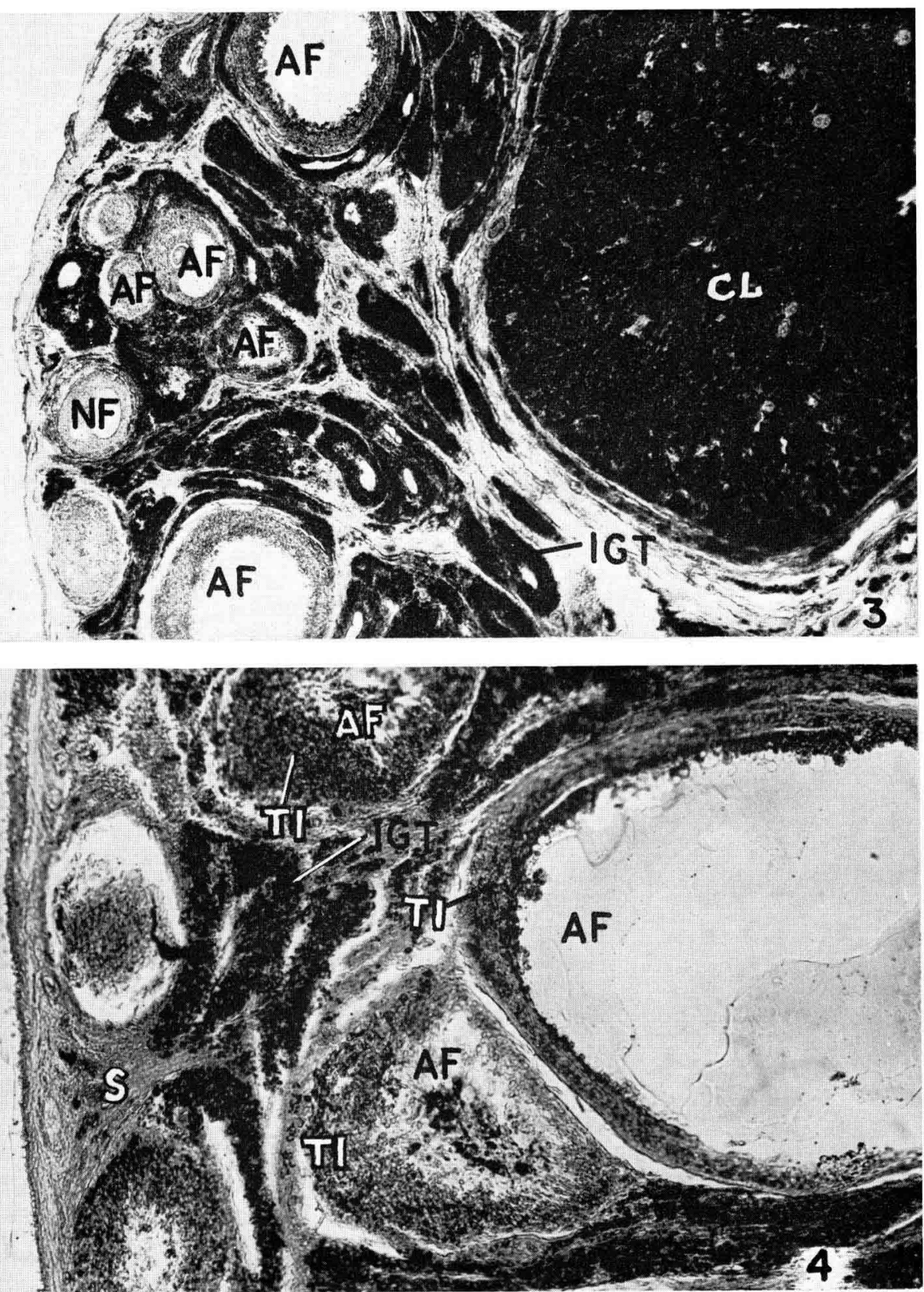

S. GURAYA 


\section{PLATE III}

\section{FIG. 5 to 8}

Portions of small atretic antral follicles from nonpregnant buffalo ovary, illustrating morphological and histochemical changes in the theca interna (TI) and granulosa (G) during the successive stages of atresia. With the start of atresia theca interna cells (TI) gradually hypertrophy and store sudanophilic lipids. After staying for sometime in the wall of atretic follicle, the thecal gland cells or interstitial gland cells (IGT) (Fig. 6) are seen to revert to the original stromal elements by losing their cytoplasm and lipids (Fig. 7, 8). The degenerating granulosa cells (DG), which accumulate coarse lipid droplets, gradually disintegrate and disappear. Finally there are left behind clear scars containing some residual interstitial gland cells which are still in the process of losing their lipids and cytoplasm.

\section{PLANCHE III}

FIg. 5 à 8

Petits follicules à antrum atrétiques d'un ovaire de bufflesse non gestante, montrant les changements morphologiques et histochimiques dans la thèque interne (TI) et la granulosa (G) au cours de l'atrésie. 

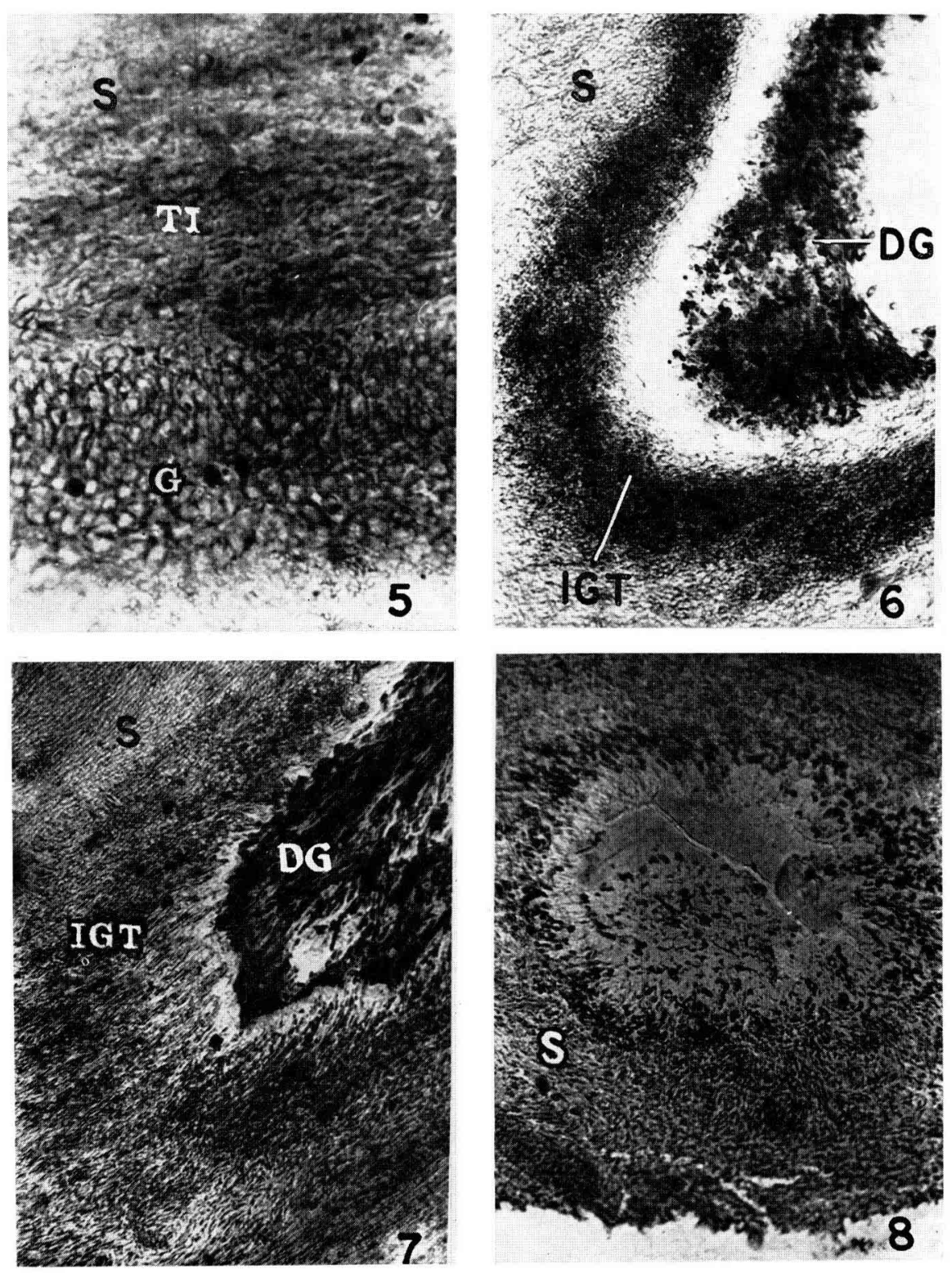